\title{
From the Desk of Editor-in-Chief
}

\section{Ramesh Chandra Sinha ${ }^{1}$}

Published online: 17 February 2020

(C) ICPR 2020

This issue of JICPR attempts to streamline distinctive contemporary Indian method of philosophizing. Philosophy is grounded in the very basics of human existence. It finds expression in the patterns of living. It raises questions and searches answers about the problems of life and world. Philosopher sharpens cognitive apparatus to understand the Ultimate Reality. Philosophizing is the process of theoretic consciousness, but it has therapeutic use also. It prepares the human being to bear the brunts of life. The development of science and technology is quite fruitful achievement for human society. Philosophizing has also been changed with the passage of time. Philosophers are concerned with the points and counter-points. The questioning is innate in Indian mind. Indian style of philosophizing transcends rationalization. Philosophy is not mere rational enquiry. It probes into the cause of sufferings. It delves deep into the depth of reality in order to get rid of ignorance. In 'Vedantic terminology', 'Avidya' is the cause of suffering. 'Avidya' can be removed through 'Aparoksha Anubhuti' which absorbs the essence of sense experience, reason intuition. Philosophical experience is integral experience. Philosophizing is not the job of erudite scholars only. Rishis of India have done a marvelous job of philosophizing. They have built excellent philosophical systems like 'Sankhya' and 'Vedant'. They have also propounded 'Yoga' philosophy which is of therapeutic use for suffering humanity. Conceptualization is free from dogmas. If we read 'Bhagvad Geeta', we find its therapeutic use because it cures us from the vicissitudes of life. It teaches human beings to live authentic life.

The themes incorporated in this volume are quite philosophical. Critical comments are welcomed.

Publisher's Note Springer Nature remains neutral with regard to jurisdictional claims in published maps and institutional affiliations.

Ramesh Chandra Sinha

rcsinha22@gmail.com

1 Patna, India 